\title{
A study on helminthiasis of cattle herds in Kachia grazing reserve (KGR) of Kaduna state, Nigeria
}

\author{
H. E. Nnabuife ${ }^{1}$, A. D. Dakul ${ }^{2}$, G. I. Dogo ${ }^{1}$, O. K. Egwu ${ }^{1}$, P. R. Weka ${ }^{1}$, I. N. Ogo ${ }^{1}$, E. O. Onovoh ${ }^{1}$ and B. O. Obaloto ${ }^{3}$ \\ 1. Parasitology Division, National Veterinary Research Institute, Vom, Nigeria \\ 2. Department of Zoology, Faculty of Natural Sciences, University of J os, Nigeria \\ 3. Animal Trypanosomiasis Division, Nigerian Institute for Trypanosomiasis Research, Vom, Nigeria. \\ Corresponding author: H. E. Nnabuife, email: ekennabusimple@yahoo.com \\ Received: 12-08-2013, Revised: 30-09-2013, Accepted: 04-10-2013, Published online: 10-11-2013
}

doi: 10.14202/vetworld.2013.936-940 How to cite this article: Nnabuife HE, Dakul AD, Dogo GI, Egwu OK, Weka PR, Ogo, I N, Onovoh EO and Obaloto BO (2013) A study on helminthiasis of cattle herds in Kachia grazing reserve (KGR) of Kaduna state, Nigeria, Veterinary World 6(11): 936-940.

\begin{abstract}
Aim: This study was conducted with the aim of determining the prevalence of helminthes in cattle and treatment intervention strategy in Kachia Grazing Reserve (KGR).

Materials and Methods: A total of 3,651 cattle from 88 households were randomly selected, sampled and examined . The sampling was spread over three (3) periods; Pre-intervention $(1,609)$, Intervention $(1,525)$ and Post-intervention (517). Both physical examination and laboratory investigation were employed in the study.

Results: This study revealed the presence of different types of helminthes in the bovine population of the KGR which include the helminth eggs of Nematodes (Oesophagostomum radiatum, Bonustonum phlebotomum, Tricuris globulosa, Cooperia pectinita, Toxocara vitulorum, Strongiloides papillosus, Strogylus langamus), Cestodes (Moneizia benedeni) and Trematodes ( Schistosoma bovis, Paramphistomum cervi, Fasciola gigantica) at different intervention periods, where by 820 (53.77\%) were positive for pre- intervention, $946(58.79 \%)$ positive for intervention and $205(39.65 \%)$ were positive for postintervention period. Among the eleven species of helminthes identified, $P$. cervi was the most prevalent in all the periods, followed by $O$. radiatum. The study also revealed that the cattle in the study area were infected with single and multiple infections. Furthermore, 498(32.66\%), 585(36.36\%) and 171(33.08\%) of cattle for the pre- intervention, intervention and post- intervention periods, respectively had single infection. However, $305(20 \%), 381(23.68 \%)$ and $37(7.16 \%)$ of the cattle for the three periods, respectively harbored multiple infections (polyparasitism) caused by two to six different parasites. The results also show that age was a factor in the abundance of the parasites in the cattle as parasites were demonstrated more in adult cattle than the young stock (calves and yearlings). Chi-square and Kruskal Wallis showed a significant difference ( $<<$ $0.05)$ in the prevalence during the three periods.
\end{abstract}

Conclusion: The present study revealed that helminthes of cattle are common in KGR; hence there is a need for regular faecal examination and routine treatment of the herds instead of treating the individual cases.

Keywords: cattle, helminths, intervention, Kachia grazing reserve, Nigeria, pre-intervention, post-intervention

\section{I ntroduction}

Among all the livestock that make up the farm animals in Nigeria, ruminants, comprising sheep, goats and cattle, constitute the farm animals largely reared by farm families in the country's agricultural system [1]. Nigeria has population of 34.5 million goats, 22.1 million sheep and 13.9 million cattle. The larger proportion of these animals' population are however largely concentrated in the northern region of the country than the southern region [1].

Cattle represents a valuable asset in both traditional and modern agriculture; they provide meat, milk, skin and draught power. Additionally they may, in a traditional society be an essential part of the social system, representing a family wealth or they can be regarded as a survival kit by nomadic people [2].

Despite its usefulness to man, cattle may be

Copyright: The authors. This article is an open access article licensed under the terms of the Creative Commons Attribution License (http://creativecommons.org/licenses/by/2.0) which permits unrestricted use, distribution and reproduction in any medium, provided the work is properly cited. infected with pathogens that are dangerous to man and other domestic animals. Such are parasites which include helminthes of Gastrointestinal Tract (GIT). Helminth parasites come in three major classifications namely cestodes (tapeworms), nematodes (round worms) and trematodes (flukes) [3]. Helminthiasis is the disease caused by the presence of helminth parasites within the GIT of an animal. All species of animals can be infected with helminth parasites. The infection usually is more severe in the very young and the very old or immuno-compromised animals [4]. Some adult animals can thrive fairly well while infected with some helminth parasites without showing obvious clinical signs, while the vast majority suffer reduced productivity under heavy worm burdens [4]. The negative impact of helminth infections on livestock productivity in tropical countries has long been established. Reports by Keyyu et. al. and Edosomwan et. al. [5,6] contained recent appraisals of this problem.

Helminth infections are important cause of production losses in livestock worldwide often nece- 
ssitating antihelminthic treatment [7]. The significance of helminthiasis has been recognized by livestock farmers right from the earliest of times and various methods have been employed by them to control helminthes in their animals including the use of medicinal plants and herbs and different grazing techniques [8]. For example, the Fulani herdsmen in Nigeria start treating calves against helminthes with medicinal plant as early as within a week of birth [9] because they recognize the importance of helminthes in calves of less than a year old. The major control method employed against helminth parasites in developing countries as elsewhere is the use of chemotherapy $[10,11]$. Mostly broad spectrum anthelmintics such as the Benzimidazoles (administerd per os) and levamisole hydrochloride (administered per os, intramuscularly and subcutaneously) are used. The total eradication of most helminthes from livestock is not practical and in some cases not even desirable as some of the parasites are necessary for conferring immunity on the host. The strategies for preventive control must involve stopping a build-up of large numbers of larvae on pasture and anticipation of periods for likely multiplication of larvae on pasture and to move animals from such pastures during those periods. In order to achieve this goal there has to be a multifaceted approach involving grazing management, use of anthelmintics and dependence on acquisition of immunity. A complete integration of these three gives the best efficient control $[8,10]$. The best forms of control of helminthes will require a basic understanding of certain principles bordering on the parasite's developmental cycle, mode of transmission and predisposing factors to infection [12,13]. Age of animals is also important in helminth control but some illiterate farmers will not understand this [14]. Most farmers in developing countries have little access to such basic information or are not interested. Therefore, they are not able to make use of such information for the control of helminthes in their livestock. In addition to this many farmers are ignorant of the crucial role of strategic deworming programs in livestock. Strategic deworming programs will reduce the worm burden in livestock and maximize the productivity of the animals in addition to ensuring the protection of other animals and humans from helminthes of zoonotic importance which can be easily transmitted from animals to man or vice-versa [4]. Control of the larval stages will ensure that the parasite's developmental cycle is broken. The breaking of the parasites life cycle can be achieved by the use of suitable anthelminthic drugs such as Levamisole Hydrochloride and various Benzimida-zoles, many of which also act on the adult stages of the parasites [11]. Apart from the use of drugs, there are husbandry practices and measures that are essential for control of helminth parasites. Farmers should avoid early morning grazing so that the animals do not take in the infective larvae of the parasite from the pasture. When the sun rises is the best time to take the animals for grazing. Rotational and zero grazing of the animals should also be carefully planned and carried out to maximize pasture consumption and encourage immunity of the animal as well as maximizing productivity [8]. According to Radostits et.al. [15], the predisposing factors to these parasitic diseases include amongst others high concentration of livestock population and that the principal problem of parasitic diseases in cattle is common in areas of highly productive lands where larger number of animals has been concentrated.

Despite this importance, helminthes are the most neglected area of Veterinary care in the developing countries (including Nigeria) due to its chronic and insidious nature, with endemic pathogenic, vectors and diseases particularly where extensive grazing is practiced [16,17].

Grazing Reserves were established in Nigeria in major cattle producing areas to stabilize the pastoral production system.Hence, various state governments have designated certain land areas for Grazing Reserve, one of which is Kachia Grazing Reserve (KGR) located in Kachia Local Government Area in Kaduna State Nigeria.

Monitoring cattle numbers and habitat conditions as well as ascertaining parasites and disease surveillance has become extremely important in monitoring adequate number of any healthy livestock. Therefore, this study is set up to determine the level of prevalence of gastrointestinal helminthes in cattle of different ages in KGR and also to come up with a baseline epidemiological data that will serve the immediate community which will be useful in the management of cattle for improved production.

\section{Materials and Methods}

Study area: The study was conducted in Kachia, the sedentary Fulani communities of KGR in Kaduna state, Nigeria. KGR is bounded by three Local Government areas which include; Kachia L.G.A., Zangon Kataf L.G.A and Kaura L.G.A.

KGR is a vast area of land with vegetation reserved by the Federal Government for Fulani cattle rearers for the purpose of grazing at one place. It is a good quality farmland with sufficient forage and water for the herds throughout the year and healthy environment for livestock [18].

Population size: The KGR comprises six contiguous 'Blocks'. These are geographically-distinct administrative region. The blocks contain 581 farmers (heads of households) and 5,252 people. The number of households per block ranges from 80 (Blocks 5 and 6 together) to 188 (Block 2). Five hundred and sixty nine households own cattle, of which there are 23,327 animals. Four hundred and fifty two of 581 households own sheep, of which there are, 5,914 animals. Three hundred and eighty six households of 581 own goats, of which there are 5,058 animals [19].

Sample size/ procedure: A total of 3,651 cattle from 
Table-1. Intervention period-related prevalence of helminth parasites in cattle in KGR, Kachia, Kaduna State, Nigeria.

\begin{tabular}{lcc}
\hline Period & Number examined & Number positive (\% infection rate) \\
\hline Pre-intervention (March-April, 2011) & 1,525 & $820(53.77)$ \\
Intervention (June-July, 2011) & 1,609 & $946(58.79)$ \\
Post-intervention (Sept.-Oct., 2011) & 517 & $205(39.65)$ \\
\hline
\end{tabular}

Table-2. Distribution of parasites of cattle during the intervention periods in KGR

\begin{tabular}{llll}
\hline Parasites & $\begin{array}{l}\text { Pre-intervention } \\
\text { No. infected } \\
\text { (\% infection rate) }\end{array}$ & $\begin{array}{l}\text { Intervention } \\
\text { No. infected } \\
\text { (\% infection rate) }\end{array}$ & $\begin{array}{l}\text { Post-intervention } \\
\text { No. infected } \\
\text { (\% infection rate) }\end{array}$ \\
\hline O. radiatum & $232(17.90)$ & $237(16.39)$ & $57(23.08)$ \\
B. phlebotumum & $112(8.64)$ & $106(7.33)$ & $12(4.86)$ \\
T. globulosa & $189(14.58)$ & $213(14.73)$ & $43(17.41)$ \\
C. pectinita & $93(7.18)$ & $45(3.11)$ & $3(1.21)$ \\
M. benedeni & $9(0.69)$ & $1(0.07)$ & $0(0.00)$ \\
T. vitulorum & $7(0.54)$ & $8(0.55)$ & $0(0.00)$ \\
S. papillosus & $76(5.86)$ & $14(0.97)$ & $1(0.40)$ \\
S. langamus & $1(0.08)$ & $0(0.00)$ & $0(0.00)$ \\
S. bovis & $0(0.00)$ & $2(0.14)$ & $3(1.21)$ \\
P. cervi & $540(41.67)$ & $736(50.90)$ & $127(51.43)$ \\
F. gigantica & $37(2.86)$ & $84(5.81)$ & $1(0.40)$ \\
\hline
\end{tabular}

Table-3. Prevalence of helminth parasites in different age groups of cattle in KGR

\begin{tabular}{lcccccc}
\hline Age group & \multicolumn{2}{c}{$\begin{array}{c}\text { Pre-intervention } \\
\text { No. infected }\end{array}$} & No. examined & $\begin{array}{c}\text { Intervention } \\
\text { No. infected } \\
\text { (\% infection rate) }\end{array}$ & $\begin{array}{c}\text { Post-intervention } \\
\text { No. examined }\end{array}$ \\
(\% infection rate) & & $39(4.76)$ & 93 & $45(4.76)$ & 27 & $3(1.46)$ \\
\hline$<$ imnths & 101 & $109(13.29)$ & 256 & $117(12.37)$ & 56 & $14(6.83)$ \\
8mn -2ys & 252 & $672(1.95)$ & 1,260 & $784(82.88)$ & 434 & $188(91.71)$ \\
$>$ 2years & 1,172 & $820(100)$ & 1,609 & $946(100)$ & 517 & $205(100)$ \\
Total & 1,525 & & &
\end{tabular}

these 88 household were randomly selected. This sampling was spread over three periods; Preintervention $(1,609)$, Intervention $(1,525)$ and Postintervention (517). Ethical consideration was obtained from Kachia Grazing Reserve Administrative Office and questionnaires were administered.

Collection of faecal samples: Fresh faecal samples were collected per-rectum of cattle by hand using plastic gloves. Each animal sampled was identified using marker pen. Samples collected were labeled and kept in cool boxes before transporting them to Parasitology Division laboratory at the National Veterinary Research Institute, Vom for further analysis.

Faecal examination: Faecal examination was done by a quantitative floatation method (McMaster technique) applied for detection of nematode and cestode eggs, while sedimentation method was used for detection of trematode eggs as described by Hansen et. al. and Soulsby [20, 21] respectively. $1 \mathrm{~g}$ of faeces was weighed for McMaster and $2 \mathrm{~g}$ for the sedimentation analysis, respectively.

Data analysis: Data obtained were subjected to statistical analysis using Chi-Square $\left(\chi^{2}\right)$ and Kruskal Wallis test [22].

\section{Results and Discussion}

Distribution and types of parasite eggs in the Preintervention, Intervention and Post-intervention periods: In March (Pre-intervention) 820 (53.77\%) were positive, intervention in June, 946 (58.79\%) were positive and finally $205(39.65 \%)$ were positive for post-intervention (Table-1).

The helminth eggs of Nematodes - Oesophagotomum radiatum, Bonustonum phlebotomum, Tricuris globulosa, Toxocara vitulorum, Strongiloides papillous, Strogylus langamus, Cooperia pectinita, CestodeMoneizia benedeni, and Trematodes- Schistosoma bovis, Paramphistomum cervi and Fasciola gigantica were identified (Table-2). The range of parasites found in this present study was almost similar to that found in Benin City- the Southern part of Nigeria by Edosomwan, E. U. and Shoyemi, O.O. [23] where they studied the various occurrences of different types of gastrointestinal helminth parasites of cattle and recorded twelve species of intestinal helminthes.

The age and season played significant role in determining helminthes community species concentration in cattle in the KGR which is in agreement with Fuentes et. al.[24]. The result shows that age was a factor in the abundance of the parasites in the animals. Parasites were observed to be more in adult animals than the young stock (calves and yearlings), and this could be due to the fact that older livestock may have been exposed more frequently to infective stages of the parasites (Table-3). This is in agreement with the report by Ibrahim et al., [25]. The present study demonstrated that $P$. cervi was the most prevalent in all the periods followed by $O$. radiatum (Table-2). The high prevalence of $P$. cervi may be attributed to the favorable environmental factors of temperature and precipitation found in the $\operatorname{KGR}[26,27]$. Another possible factor is that the Fulanis in the KGR through responses to questionnaire revealed that the young stock received 
Table-4. Single and mixed helminth infections among cattle during pre-intervention, intervention and post-intervention periods in KGR

\begin{tabular}{llll}
\hline $\begin{array}{l}\text { Parasites } \\
\text { (frequency of } \\
\text { occurrence) }\end{array}$ & $\begin{array}{l}\text { Pre-intervention } \\
\text { No. infected } \\
\text { (\% infection rate) }\end{array}$ & $\begin{array}{l}\text { Intervention } \\
\text { No. infected } \\
\text { (\% infection rate) }\end{array}$ & $\begin{array}{l}\text { Post-intervention } \\
\text { No. infected } \\
\text { (\% infection rate) }\end{array}$ \\
\hline 0 & $722(47.34)$ & $643(39.96)$ & $309(59.77)$ \\
1 & $498(32.66)$ & $585(36.36)$ & $171(33.08)$ \\
2 & $192(12.59)$ & $251(15.60)$ & $33(6.38)$ \\
3 & $74(4.85)$ & $69(4.29)$ & $4(0.77)$ \\
4 & $33(2.16)$ & $38(2.36)$ & $0(0.00)$ \\
5 & $5(0.33)$ & $16(0.99)$ & $0(0.00)$ \\
6 & $1(0.07)$ & $7(0.44)$ & $0(0.00)$ \\
\hline
\end{tabular}

more attention from them than the adults with believe that the adult cattle have outgrown parasitic attacks which is in agreement with Ibrahim et. al. [9].

The significant effect of season on helminthes concentration in this study is evident in the parasite prevalence observed in the different periods. The higher prevalence observed during the intervention period (Table-1) could be ascribed to the fact that stool collection was done during the wet season. During this period, high moisture content increased development of larvae and abundant pasture, thus resulting in increased contact between the host and parasites. These findings are similar to Fakae [28] and Bhattacharya, et. al, [29] who recorded higher incidence of parasitic infection during rainy season in Nigeria and India, respectively. Single parasite infections are more common than mixed (multiple) infections among the infected cattle examined irrespective of the season in all the periods (Table-4). Lower prevalence was recorded during the pre-intervention and postintervention periods which were carried out during the dry season (Table-1). In addition to seasonal influence, the low post-intervention prevalence could be ascribed to the effectiveness of the deworming intervention of the animals using a broad- spectrum antihelmintic bolus containing a combination of $60 \%$ oxyclozanide and $40 \%$ levamisole hydrochloride (Kepxan Bolus, Kepro®, Holland). In general, the observations made on the low prevalence during the dry season in this study were in accord with the work of Fabiyi [30] on seasonal fluctuations of nematode infestations in the Savannah belt of Nigeria. Statistically, there was a significant difference in the prevalence of helminth infections in cattle at the KGR during the three periods under investigation $(\mathrm{p}<0.05)$.

\section{Conclusion and recommendation}

The results of this study indicate that helminthes of cattle are common in KGR. However, it was also observed that herd-herd treatment takes care of not only clinical cases, but subclinical cases as well. Added to the above problems, is the cost of veterinary services which is of great concern for farmers in developing countries due to their low level of income [31].

Therefore, our recommendations are as follows:

1. Farmers in KGR are to be enlightened more on the need to treat the herds instead of treating the individual cases.

2. There is need for regular faecal examinations of the cattle or routine prophylactic treatment of the herds.

3. Government provides Grazing Reserve such as KGR for all the nomadic fulanis in Nigeria for this will help to trace and effectively tackle the problems such as helminth infections when they are together at a particular place.

\section{Authors' contributions}

HEN, ADD and GID conceived of the study and participated in its design. GID and OKE coordinated the field activities. HEN, OKE, PRW, EOO and BOO carried out the collection and analysis of the samples. HEN, ADD and GID carried out the statistical analysis. HEN, ADD and INO drafted and revised the paper. All authors read and approved the final manuscript.

\section{Acknowledgements}

This work was funded in part by the UK's Biotechnology and Biological Sciences Research Council (BBSRC) under the Combating Infectious Diseases in Livestock for International Development (CIDLID) scheme and European Union's Seventh Framework Program (FP7/2002-2013) under grant agreement No. 221948, Integrated Control of Neglected Zoonosis (ICONZ) in collaboration with National Veterinary Research Institute (N.V.R.I.), Vom, Plateau State, Nigeria. Authors wish to acknowledge M. S. Ahmed (EDVR) and the Management of N.V.R.I., Vom for sponsorship. We also recognize the various contributions made by the staff of the Parasitology Division, N.V.R.I., Vom, particularly J. Kamani, Godwin Ojoko, Pam Mancha, and Ego Kennedy for their valuable suggestions and help in collection and analysis of samples, S. Welburn, Ayodele Majekodunmi, Marie Durotoy, and Vincenzo Lorusso (Division of pathway Medicine, Edinburgh University Medical School, UK). Appreciation also goes to Charles Dongkum, Gyang Balak, C.O. Idehen and Langs Tok for their assistance in the field.

\section{Competing interests}

The authors declare that they have no competing interests.

\section{References}

1. O. A. Lawal-Adebowale, (2012) Intech- Dynamics of Ruminant livestock management in the context of the Nigerian Agricultural System 4: 61-80.

2. Fabiyi, J.P. (1984) Coping with parasitic disease problem in Nigeria. Livestock Farmers Series 4: 13. 
3. Tibbo, M., Aragaw, K., Teferi, M. and Haile, A. (2011) Effect of strategic helminthosis control on mortality of communally grazed Menz lambs of smallholders in the cool central Ethiopian highlands. Small Ruminant Research 90(1-3): 58-63.

4. Bamaiyi, P. H. (2012) Factors militating against the control of helninthosis in livestock in developing countries. Veterinary World 5(1): 42-47.

5. Keyyu, J.D., Mourad, J., Kursgarerd, N.C.A.A and Kassuku (2005) Epidemiology of Fasciola gigantica and Amphistomes in cattle on Traditional small-scale dairy and large scale dairy farms in the Southern Highland of Tanzania. Tropical Animal Health and production 37: 303-314.

6. Edosomwan, E. U. and Ewarami, T. J. (2012) Ticks and helminth parasites of Cattle at Ikpoba hill abattoir Benin City, Edo State, Nigeria. Biological and Enviromental Sciences Journal for the Tropics, 9(1): 179-183.

7. Vercruysse, J. and Clarebout, E. (2001) Treatment vs. nontreatment of helminth infections in cattle: Defining the thresholds. Veterinary Parasitology, 98: 195-214.

8. Bukhari, S., and Sanyal, P. K. (2011) Epidemiological Intelligence for Grazing Management in Strategic Control of Parasitic Gastroenteritis in Small Ruminants in India - A Review. Vet.World, 4(2): 92-96.

9. Ibrahim, M. A., Nwude, N., Aliu, Y. O. and Ogunsusi, R. A. (1983) Traditional concepts of disease and treatment among Fulani herdsmen in the Kaduna State of Nigeria. ODI Pastoral Network Paper 6C.

10. Aragaw, K., Teferi, M., Haile, A. and Tibbo, M. (2010) Effects of strategic helminthosis control on age at first lambing and lambing interval of communally grazed Menz ewes in Ethiopia. Livestock Science, 135(1): 38-43.

11. Sargison, N. D. (2011) Pharmaceutical Control of Endoparasitic Helminth Infections in Sheep.Veterinary Clinics of North America: Food Animal Practice, 27(1): 139156.

12. Moore, L. S. P. and Chiodini, P. L. (2010) Tropical helminths. Medicine, 38(1), 47-51.

13. Roepstorff, A., Mejer, H., Nejsum, P. and Thamsborg, S. M. (2011) Helminth parasites in pigs: New challenges in pig production and current research highlights. Vet. Parasitol., 180(1-2): 72-81.

14. Chitra, R., Rajendran, S., Prasanna, D. and Kirubakaran, A. (2011) Influences of age on the prevalence of Parasitic infections among donkeys in Erode district, Tamilnadu, India. Vet. World, 4(6): 258-259.

15. Radostits, O.M., Blood, D.C and Gay, C.C. (1994) Veterinary Medicine. A text book of the disease of cattle, sheep, pigs and horses, 8th edn. 1226-1235.

16. Magona J.W., Walubengo J. and Odimin J.T (2008) Acute haemorrhagic syndronae of bovine trypanosomoses in Uganda. Acta Tropica, 107(2): 186-191.

17. Bizimenyera, E.S., Swan, G.E., Eloff, T.N., Meyer, S. and
Naidoo, V. (2008) Efficacy of Peltophorum affricanum sond. (fabaceace) extracts on Haemonthus contortus and Trichostrongylus colubriformis in sheep. Journal of Animal and Veterinary advances, 7(4): 364-371.

18. Okali, C. and Sule, B (1980) The role of pastoralists' organizations in defining land use systems in Kaduna State. International Cmmunication, ILCA Subhumid Zone Program, Kaduna.

19. Kachia Grazing Reserve Administrative Census (2010) Summary of plans for Intergrated Control for Neglected Zoonosis (ICONZ) Nigeria Case Study.

20. Hansen, J. and Perry, B. (1990) The Epidemiology, Diagnosis and Control of Gastro-intestinal Parasites of Ruminants in Africa. A Handbook, (ILRAD) Nairobi, Kenya, pp 25-50.

21. Soulsby E.J.W. (1982) Helminths, Arthropods and Protozoa of Domesticated Animals. $7^{\mathrm{th}} \mathrm{Edn}$. Lea and Febiger, Philadelphia: Bailliere Tindall, London, pp. 212-258.

22. Sokal R.R. and Rohlf F.J. (2001) Biometry Freeman Publishers. 887pp.

23. Edosomwan, E. U. and Shoyemi, O.O. (2012) Prevalence of gastrointestinal helminth parasites of cattle and goats slaughtered at abattoirs in Benin City, Nigeria. African Scientist. 13(2): 109-114.

24. Fuentes, M.V., Saez, S., Trelis, M., Galan-Puchades, M.T., Esteban, J.G. (2004) The helminth community of the wood mouse, Apodemus sylvaticus , in the Sierra Espuna , Murda, Spain, Journal of Helminthology, 78(3):219-223.

25. Ibrahim, M.M., Al Ghamdi, M.A., Al Ghamdi and M.S. (2008) Helminthes community of Veterinary Importance of Livestock in Relation to Some Ecological and Biological Factors. Turkiye Parazitoloji Dergisi, 32: 42- 47.

26. Gupta, B.V. and Parshad S. Giraya (2004). Maturation of Paramphistomum cervi in sheep in India. Veterinary Parasitology, 15:239-245.

27. Sukhdeo, M. and Sukhdeo, S. (2004) Trematode behavior and perceptual worlds of parasites. Canadian Journal of Zoology, 82: 292-315.

28. Fakae, B. B. (1990) The epidemiology of helminthosis in small ruminants under the traditional husbandry system in eastern Nigeria. Veterinary Research Communication, 14 (5) : 381-391.

29. Bhattacharya, D.K. and Ahmed, K. (2005) Prevalence of helminthic infection in cattle and buffaloes. Indian Veterinary Journal.82: 900 -901.

30. Fabiyi, J. P. (1973) Seasonal fluctuations of nematode infestations in goats in the Savannah Belt of Nigeria. Bulletin of Epizootic Diseases of Africa, 21:277-286.

31. Reddy, M. S. and Rao. B. S. (2011) Relationship between Affordability to pay for the Veterinary Services and profile characteristics of Dairy farmers. Veterinary World, 4(6): 266-268. 